\title{
An African Christian Perspective on the Veneration of the Saints or the Ancestors
}

\author{
Anthony Kofi Anomah*1,2 Peter Addai-Mensah, $\mathrm{PhD}^{3}$ \\ 1. PhD candidate, Department of Religious Studies, Kwame Nkrumah University of Science and Technology, \\ Kumasi, Ghana \\ 2. Rector of the Spiritan University College, Ejisu Ashanti, Ghana \\ 3. Senior Lecturer, Department of Religious Studies, Kwame Nkrumah University of Science and Technology, \\ Kumasi, Ghana
}

\begin{abstract}
Almost all religions believe in life after death. Christians believe that their deceased relatives and Church members who were baptised before they died would rise to new life in Christ after death. However, some Pentecostal and Charismatic Christians find it difficult to accept the fact that our deceased brothers and sisters (who are called by different names, saints or ancestors) are alive and deserve honour or recognition from the living. Africans venerate their deceased brothers and sisters who lived impeccable and irreproachable lives while they lived on this earth. In the same way some Christians, especially Catholics, Anglicans and others in public ceremonies canonize their deceased brothers and sisters who lived lives worthy of emulation and call them saints. They set aside some days in the year when they are publicly venerated in their liturgies and celebrate their entrance into eternity with God. In this article the writer argues that both Catholics and Africans are doing nothing wrong when they venerate their brothers and sisters as heroes in this way. They are only giving them honour like we do to our national heroes and ask for their intercession in prayer. Although Christians and Africans call their deceased members who lived exemplary lives by different names (Saints and Ancestors respectively), they venerate them in similar ways and the Saints or Ancestors play similar roles in the lives of their living members, notwithstanding some dissimilarities.
\end{abstract}

Keywords: Veneration, Worship, Saints, Ancestors.

DOI: $10.7176 / \mathrm{JPCR} / 45-02$

Publication date:October $31^{\text {st }} 2019$

\section{Introduction}

One of the Christian practices or beliefs in religion that is so widely misunderstood by both Christians and nonChristians is the belief in the veneration of Saints. In the case of Christians, especially those in the Catholic and Anglican denominations, Saints are venerated while practitioners of African Traditional Religion venerate the Ancestors. Many people confuse the word "veneration" with "worship" and so many non-Catholics think that Catholics worship the Saints. In response to this erroneous belief, Sarpong $(2016,49)$ said, "The Church does not worship Saints nor adore them. Only God is worshipped and adored (cfr Mt. 5:10). The Saints are venerated." Catholics venerate the saints when they emulate their lives and spirituality and pass their supplication through them to God. They ask the Saints to pray to God for them just as people ask their colleagues or friends to pray for them. Christians who profess the Nicene Creed or the Apostles Creed confess a belief in the communion of Saints (i.e. the communion of the saints, the living and the dead). In this article, I argue that the belief in the Veneration of Saints and the Veneration of Ancestors compare favourably with each other; and suggest that both African Christians and non-Christians are not doing anything wrong when they Venerate their Saints or Ancestors. In this regard, I argue that there appears to be no compelling reason why African Christians at baptism were made to take names of Saints from Europe and America instead of the names of their African Ancestors who had lived exemplary lives comparable to the European and American Saints. I am very happy to state that today there are also African Saints like Charles Lwanga and his companions, Kizito, the Martyrs of Uganda, Matthias Mulumba, Josephine Bakhita of Sudan and many others whom African Christians could emulate.

\section{Methodology}

This article was written based on data collected for a doctoral study from Ejisu Juaben Municipality between 20017 and 2018. The Convergent Parallel Mixed Methods Case Study Approach was used. Questionnaires were distributed to 377 respondents in the Roman Catholic Church, the Methodist Church Ghana and the Church of Pentecost in proportion to the number of Christians in each Church from 16 years and above in the following ratio: 151, 132, 94 respectively and analysed using the Statistical Package for Social Sciences software. A purposive interview of nine Bishops, priests and pastors in those Churches also provided data that were analysed. Documents and other publications relevant to the subject were also perused and analysed. 


\section{Who are the Saints and How Are they Venerated?}

Sarpong $(2001,29)$ defined a Saint as "a human person who, in the opinion of the Church, has distinguished himself by the practice of virtue to a heroic degree, and is now in the company of the blessed enjoying the sight of God." This declaration of the Church entitles the dead person to receive a general veneration in the Universal Church. This is on account of his/her dignity and close union with God. The veneration of the Saints is distinct from the worship due to God alone (adoration). "In the Catholic Church (both the East and the West) the act of canonisation is reserved to the Holy See and occurs at the conclusion of a long process requiring extensive proof that the person proposed for canonisation lived and died in such an exemplary and holy way that he or she is worthy to be recognised as a saint (Sarpong, 2016, 57)."

Sarpong observed that Christians venerate their Saints in many ways, including celebrating their feasts, displaying their statues or images and adorning them with flowers and lights. In addition, "the imitation of the lives of the Saints is another way of venerating them. However, the most usual way is by praying to them. But any prayer directed to them is a prayer of intercession, through which the living wish the Saints to intercede with God on their behalf (Sarpong, 2001, 30)." The Roman Catholic Church teaches that the living, the souls in purgatory and the Blessed constitute one Church. This teaching is called the communion of saints. Therefore, the Blessed in heaven present to God the pleas and petitions of their brothers and sisters on earth. They take a very active interest in the living, pilgrims on earth, and help them in their spiritual temporal necessities (Sarpong, 2001, 31).

According to Sarpong, the Saints are venerated when Christians honour them for the edifying lives they lived; and pray to God through them. When Christians address prayers to the Saints, they are not asking for help from the Saints but asking for the intercession of the Saints to direct their prayers to the Supreme God. Sarpong $(2016,50)$ argues that if in ordinary life, we ask our friends to pray for us when we are in difficulty or when we want something like a pass in examination, then why can't we ask the Saints to pray for us?

In his book, The Catholic Answer Book, Peter M. J. Stravinskas $(1990,39)$ said,

Catholics agree that Jesus is the sole mediator between God and man but that in no way makes prayer to the saints useless or wrong. Many times one finds the New Testament recommending intercessory prayer (cf. Col 1:9; 2 Thess. 1:11; 2 Thess. 3:1; Jas. 5:16), and very few Christians seem to have a problem with seeking the prayers of a fellow believer. But what difference should that make to one who affirms the resurrection of the dead? After all, we read that all are alive in Christ (cf. 1 Cor. 15:22).

For Stravinskas $(1990,39)$,

The teaching of the Church is clear: Jesus Christ is the sole mediator between God and man. No other person in heaven or on earth can take His place. The role of Mary or any other saint is to lead the believer to Christ... Therefore, it is important to distinguish between the adoration owed to the Persons of the Blessed Trinity and the veneration given to the saints.

At the wedding feast at Cana in John 2: 1-3, Mary played the role of an intercessor for the married couple when she told Jesus that the couple had no wine:

Three days later there was a wedding at Cana in Galilee. The mother of Jesus was there, and Jesus and his disciples had also been invited. When they run out of wine, since the wine provided for the wedding was all finished, the mother of Jesus said to him, 'They have no wine.'

Moreover, Stravinskas (1990, 39-40) said,

Catholics use medals and statues, but not as talismans or as objects of worship in violation of the First Commandment. Rather, these are intended to be reminders or aids to devotion which focus one's attention on prayer and the practice of virtue. It would be a rare husband who did not carry in his wallet a photo of his wife and children, not because he worships the photo or his family, but because he loves his family and wishes to have a visual representation of them on his person... if the heroes of nation can be honored, why not the heroes of the Church.... Prayer to Mary (or to any of the other saints) is not an end in itself but is intended to be a means by which one is led to a deeper union with her Son.

\subsection{Who are the Ancestors and How Are they Venerated?}

According to Asare Opoku $(1978,35)$, "West African societies believe that, after death, the departed ones enter into a spiritual state of existence. Birago Diop, the Senegalese poet, captures vividly this general African attitude in his poem about the continued existence of the ancestors." Africans believe that "those who are dead are not gone...the dead are not dead." Asare Opoku $(1978,35)$ argues that "The dead are believed to be everywhere, at any time; they continue to live but in another kind of existence. To him, "the ancestors are always revered and held in high esteem." Similarly, Ekenga-Metuh $(1987,147)$ said, "Ancestors are intermediaries between God and man and elder members of the family and are venerated as such, not worshipped." The ancestors are those who once lived among us in human societies but now live in the spirit realm. 


\subsection{Ancestral Worship?}

Sarpong $(2001,130)$ argues that Africans do not worship the Ancestors. He said,

The ancestors are not worshipped. They are no deified. The ancestors remain human beings, relatives of the living and they are referred to as such...no African will consider an ancestor as a god, although there are cases of exceptional nature where an ancestor has come to be regarded as a god.

Sarpong $(2001,152)$ observed,

Let it be stressed from the beginning that the Asante do not think of their ancestors as gods. They were human beings on earth and remain human in incorporeal existence where they are now. 'They are therefore considered, not as gods, but as relatives' who see us and have sympathy for their relatives on earth. Only their form as mundane creatures has changed.

To qualify to be an ancestor, certain conditions must be fulfilled, including a person's conduct while alive and the manner of death of that person. According to Asare Opoku $(1978,36)$, "the Akans of Ghana believe that to become an ancestor one must have lived a life worthy of emulation, an exemplary life; one must also have lived to a ripe old age and have had children." Thus, a person who dies childless cannot be considered as an ancestor. The person must also have died a good death. A death is not good if it occurs as a result of suicide, an accident, any form of violence, or an unclean disease such as lunacy, dropsy, leprosy and epilepsy. Persons who die in such situations do not qualify to be ancestors (Asare Opoku, 1978, 36).

\subsection{The Belief in Ancestors}

R. S. Rattray in his emphatic study of Asante religion and culture portrayed the Asantes' cosmology as an active universe, meaning that, notwithstanding missionary attitudes, Asantes had a viable cosmology that maintained an effective social order (Kalu, 1979, 14). Human beings are at the centre of this universe. They move from birth through various roles in the human world to death. Death is not the end of life. People consort with those in the spirit world while still alive until they are called to join them (Kalu, 1979, 14). The ancestors are actively involved in the affairs of the family on earth. They help them in their struggles and provide support in times of difficulties. The only difference is the kind of involvement. They are invisible and possess spiritual powers that they can use on behalf of their human families for good or evil, depending on the type of relationship that exists between the living and the dead members of their family (Kalu, 1979, 14). There are also evil spirits who move around the human world. They are those who did not live good lives on earth, died bad deaths, had their corpses mutilated, did not have proper burials, or are generic evil spirits. The presence of evil spirits in the world challenges human life and existence, therefore, ancestral veneration is a series of rituals designed to harness the resources of the good deities in order to ward off the actions and control of the evil spirits (Kalu, 1979, 14-15). The ancestors are the intermediaries between men and God. The ancestors know the needs of their family members whom they have recently been with. They also have full access to the channels of direct communication with God or indirectly through their own forefathers. Therefore, relatives approach them more often for minor needs of life than they approach God. Even if the ancestors cannot perform miracles or extraordinary deeds to help their relatives in need, people still have a sense of psychological relief when they pour out their troubles before their seniors who have a share in both worlds (Mbiti, 2016, 108).

In Asante religious beliefs, death is not a barrier between the living and the dead. The dead and the living form one community and the means of communication between them are natural and well developed. The living and the dead are mutually dependent, and a certain amount of goodwill exists between them. What the dead cannot do for themselves, the living must do for them. And what the living must know, but do not, the dead can tell them if properly interrogated (Duncan, 2016, 1925, 225). The ancestors form an integral part in the community. They are intermediaries between the physical and the spiritual world. The living ensures that the ancestral spirits are happy at all times, failure to do so could lead to disaster. The ancestral spirits have power to bring calamities to the living if they are not pleased. When things go wrong, people resort to the ancestors to find the cause. Asare Opoku $(1978,39)$ puts it this way,

The dead do not severe their links with their kinsmen but continue to be members of their individual families, fulfilling their obligations as elders. Thus, they are considered active members of the families. The relationship between the dead and the living is symbiotic as each group has a part to play for mutual benefit. The dead still show a keen interest in the affairs of the living and the living in turn have a duty towards the dead.

From the above analyses, it is evident that communities appeal to ancestors for their intercession in times of need. Similarly, individuals resort to veneration of ancestors, and the aid of their extended family circle for help when they need them. There is extensive room for appropriating more gods if they prove effective in controlling space-time events (Kalu, 1979, 16).

In traditional African societies the cosmology is tightly constructed because of the precariousness combatting evil forces, thereby creating openings for religious change (Kalu, 1979, 17). 
The African family comprises the unborn, the living and the dead. This idea is similar to the Catholic doctrine of "the communion of saints" comprising the Church Suffering (the dead), the Church Militant (the living) and the Church Triumphant (the saints). John Paul II (1995, 43) in his Post Synodal Apostolic Exhortation, Ecclesia in Africa, affirmed that "ancestral veneration is the preparation for belief in the Communion of the Saints." Africans believe intuitively that the dead continue to live and remain in communion with the living (John Paul II, 1995, 43). Therefore, Africans are not doing anything strange when they place importance on the veneration of their ancestors. The veneration of ancestors is in line with Christian teachings. According to Conteh, ancestors are the spirits of deceased males and females who have been recognised after death as having lived good lives and have been included in the community of the venerated dead (Conteh, 2012, 23). They are spirits in the sense that they are no longer visible. However, they are not spirits in the sense that they are like Divinities or God.

Sarpong argued that the belief in the existence of the spirits of the dead and the influence they have over the living is found among all people, and in every conceivable religion and culture. Christians believe in saints who are only good Christians who are dead and are believed to be in heaven enjoying eternal bliss with their Creator and Father. Just as Catholics venerate Saints, Africans also venerate their ancestors. The belief in ancestors and their veneration therefore, are not peculiar to any age, religion or society. Death is a necessary condition for one to be considered an ancestor but does not automatically qualify someone to be an ancestor. Certain conditions were expected to have been fulfilled while the deceased was alive to qualify him/her to be an ancestor.

The first condition for one to be an ancestor is to be dead (Sarpong, 2002, 98). You cannot have a living ancestor. There is no living ancestor and there cannot be one. One can be an ancestor to a particular lineage, clan, town, chiefdom or tribe as the case may be. However, there is no such thing as the ancestors of a religion, corresponding to the saints of the Christian religion.

The second condition is that one must die a "good death." As indicated earlier, one who dies through certain diseases such as leprosy, epilepsy and small pox; a tragic death such as drowning, accidentally shot, killed by a falling tree, dying in child-birth, accused of being a witch cannot be an ancestor. On the contrary, Sarpong (2002, 33) argued that the way one dies, does not necessarily influence one's status as a Saint. It does not matter whether one is killed by the most dreaded or "unclean" disease or dies suddenly or tragically through an accident or not, one could be numbered among the greatest Saints (Sarpong, 2001, 33). In this regard, the requirements or qualification for being an ancestor is even more stringent than those of saints.

Thirdly, one must have led a good irreproachable life (Sarpong, 2002, 98). A thief, a murderer, a rapist cannot be an ancestor. No one wants him/her in his/her company. His/her spirit is unreliable. This principle agrees with the Christian practice of naming a Saint.

\section{Similarities Between the Veneration of Saints and the Veneration of Ancestors}

In the light of the above, I agree with Sarpong in the sense that there is a similarity between the Asantes' conception of the ancestor and the Roman Catholic Church's doctrine about Saints. The ancestors were once human beings on earth. They are now spiritual but remain human. They take interest in the affairs of the living. The living prays through them as intercessors (intermediaries) as they do through the saints, so that they may assist them in their own way. The ancestors are now in a position to help the living because of the "good" life they had lived while on earth (Sarpong, 2001, 32). These are exactly the same role(s) played by the Saints when Christians venerate them.

Therefore, according to Sarpong $(1974,33)$ when Christians call their dead members Saints and refer to those of Africans as ancestors, they are not expressing different ideas. Both words express ideas about people who once belonged to their religious groups, are now dead, and are supposed to be in a position of influence over the living. Just as the Saints are presented as models to Catholics to imitate, so do the Asantes present their ancestors to the living Asantes to imitate them as far as it is possible.

The Asantes believe that an ancestor must have been an adult who had lived up to a mature age. Therefore, $\mathrm{s} /$ he who dies a baby or infant, unless in a strictly exceptional case cannot be an ancestor. However, unlike the ancestor, anybody can be proclaimed a Saint irrespective of whether s/he is an adult, adolescent, an infant or a baby. Neither marriage nor celibacy disqualifies one from canonisation.

Conteh $(2012,23)$ argued that the graves of the ancestors and their appearances in dreams remind us that the ancestors are in our midst. They are accessible and do not constitute a threat to the living in any way.

In a doctoral research conducted in Ejisu Juaben Municipality in 2017, I asked respondents about what Christianity shares in common with Asante Traditional Religion and whether Veneration of Saints and Veneration of Ancestors have anything in common. Table 1 and Table 2 show the responses given by the respondents. 
Table 1: Respondents' view on what Christianity shares in common with Asante Traditional Religion: "Belief in ancestral veneration (communion of saints)"

\begin{tabular}{|c|c|c|c|c|}
\hline Responses & Frequency (n) & $\begin{array}{r}\text { Frequency II } \\
\text { (n2) }\end{array}$ & $\begin{array}{r}\text { Percentage } \\
(\%)\end{array}$ & $\begin{array}{r}\text { Percentage II (\% } \\
\text { n2) }\end{array}$ \\
\hline I strongly disagree & 42 & \multirow[t]{2}{*}{105} & 11.2 & \multirow[t]{2}{*}{28.0} \\
\hline Disagree & 63 & & 16.8 & \\
\hline Neither agree nor disagree & 45 & 45 & 12.0 & 12.0 \\
\hline I agree & 131 & \multirow[t]{2}{*}{214} & 35.0 & \multirow[t]{2}{*}{59.9} \\
\hline I strongly agree & 83 & & 24.9 & \\
\hline Total & 374 & 374 & 100 & 100 \\
\hline Missing Number & 3 & 3 & & \\
\hline
\end{tabular}

Table 1 shows that out of 374 respondents, 214 (59.9\%) agreed that Christianity and Asante Religion share in common the belief in ancestral veneration (i.e. the Roman Catholic Church doctrine of veneration of saints) while 105 (28\%) disagreed. Three (3) respondents did not answer the question. The analysis of the denominations shows that there were some differences in beliefs between Roman Catholic Christians and Protestant Christians. Whereas $110(75.3 \%)$ Roman Catholics agreed that ancestral veneration and veneration of saints have things in common, 75 (56\%) Methodists and 39 (59.9\%) Pentecostals disagreed that they share things in common. However, Roman Catholics believe that both saints and ancestors refer to dead people who lived holy lives while they were alive and are given to Christians or Asantes as models of emulation. While Christians call them Saints, Asantes call them Ancestors but they perform similar role and relate with the living in a similar manner. Both saints and ancestors are interested in the wellbeing of the living. The way this role is described is a matter of semantics or terminology.

Table 2 Respondent on whether ancestral veneration is the same as veneration of saints

\begin{tabular}{|l|r|r|}
\hline Response & Frequency (n) & Percentage (\%) \\
\hline No & 247 & 69.8 \\
\hline Yes & 107 & 30.2 \\
\hline Total & $\mathbf{3 5 4}$ & $\mathbf{1 0 0}$ \\
\hline Missing Number & $\mathbf{2 ~ 3}$ & \\
\hline
\end{tabular}

Source: Fieldwork 2017

Table 2 indicates that out of the 354 respondents, the majority of them, 247 (69.8\%) disagreed that ancestral veneration is the same as the veneration of saints while 107 (30.2\%) agreed. Twenty-three (23) respondents did not answer the question. When these numbers were analysed according to religious denominations, 89 (64\%) Roman Catholics, 97 (74.6\%) Methodists and 50 (58.8\%) Pentecostals disagreed that they are the same.

In a related questionnaire, the results indicated that $25.1 \%$ versus $13.3 \%$ Roman Catholics, $27.4 \%$ versus 9.3\% Methodists and $14.1 \%$ versus $7.6 \%$ Pentecostals disagreed that ancestral veneration and veneration of saints are the same.

When I asked respondents whether it is against Christianity to venerate ancestors or whether the veneration of saints is syncretic, there were divergent views from interviewees depending on whether they were Roman Catholics or Protestants. A female Methodist pastor responded that "veneration of ancestors is against Christianity; it is superstitious and syncretic." However, majority of Roman Catholic respondents agreed that the veneration of ancestors is not against Christianity. Rather, it is the same as the veneration of saints in the Roman Catholic Church. A Roman Catholic interviewee responded that Roman Catholics believe "ancestral veneration is not against Christianity. Ancestral veneration in itself is not superstitious. It depends on how it is done." He further explained,

It depends upon one's idea of the identity of the ancestors. Ancestors, in the context of the Roman Catholic understanding, are worth venerating. However, the traditional idea of ancestors which is nebulous will call for a real discernment in embarking upon their veneration (Interview, 2017).

Another interviewee answered, "No. Ancestral veneration is a remembrance of our departed ones who are recognized as worthy of emulation like the saints. It is a sign that we are still in communion with them" (Interview, 2017).

Moreover, "For the traditional Asante, ancestral veneration is not superstitious, nor is it syncretic. It is the Christian who sees it as such. It is not a belief in omens. It is an acknowledgement that we are still united. The Asante (African) concept of socialism is based on familyhood which comprises the living, the dead, and those yet to be born" (Interview, 2017).

The writer recommends that in order to make African Christians feel at home, they should be encouraged to use the names of local Saints (Ancestors) which are meaningful to them at baptism instead of adopting EuroAmerican names. 


\section{Conclusion}

In conclusion, it is plausible to say from the foregoing analyses that the term "Ancestor" as used by Africans for their exemplary deceased members who are found to be worthy of emulation and veneration is similar to the term "Saint" used in the Roman Catholic Church and other Christian denominations. Moreover, the roles played by the Ancestors in African societies are similar to the roles played by the Saints in the Roman Catholic Church; and the veneration given to the Ancestors and the Saints are both legitimate. Therefore, the African is not doing anything wrong if $\mathrm{s} / \mathrm{he}$ venerates his/her Ancestors and ask for their intercession in prayers when s/he pours libation. In the same way, the Catholic who venerates the Saints is not doing anything contrary to the Scriptures barring any excesses and abuses. Both the Ancestors and the Saints are proposed to Africans and Catholics as people worthy of emulation. Moreover, because of they are spirits and are believed to be closer to God, they are in positions to intercede for the living in their needs.

\section{References}

Appiah-Kubi, K. \& Torres, S. (Eds.) (1979). African Theology En Route. New York: Orbis Books.

Asare Opoku, K. (1978). West African Traditional Religion. (Accra: FEP International Private Limited.

Conteh, S. P. (2012). Essays in African Religion and Christianity. Accra: Cynergy Media Ent.

Ikenga-Metuh, E. (1987). Comparative Studies of African Traditional Religions. (Onitsha: IMICO Publishers.

John Paul II. (1995). Post Synodal Apostolic Exhortation, Ecclesia in Africa (On the Church in Africa). Vatican City: Libreria Editrice Vaticana.

Kalu, O. U. (1979). "Church presence in Africa: A historical analysis of the evangelisation process.” In: K. Appiah-Kubi \& S. Torres, African theology en route (Maryknoll, New York: Orbis Books.

Mlenga, J. (2016). Dual Religiosity in Northern Malawi: Ngonde Christians and African Traditional Religion. Lilongwe: Baptist Press.

Sarpong, P. K. (2016). Archbishop Sarpong Explains Key Christian Topics. (Accra: SNAM Press. (2002). Peoples Differ: An Approach to Inculturation in Evangelisation. Legon-Accra: Sub-Saharan Publishers. (2001). Ancestral Stool Veneration in Asante, Revised Ed. Kumasi: Good Shepherd Publishers Ltd. (1996). Libation. Kumasi: Good Shepherd Publishers Ltd. . (1974). Ghana in Retrospect: Some Aspects of Ghanaian Culture: Accra: Ghana Universities Press.

Stravinskas, P. M. J. (1990). The Catholic Answer Book. Huntington, IN: Our Sunday Visitor Publishing Division. 